\title{
Potential Use of Rum Distillery Slops as Animal Feed Supplement II. Nitrogen Content of Mycelial Growth in Slops ${ }^{1}$
}

\author{
Isabel M. de González and Nivia F. de Murphy ${ }^{2}$ \\ ABSTRACT
}

Rum distillery slops proved to be a valuable medium for the growth of molds rich in mycelial protein. High reductions of BOD and total sugar content of the medium were obtained. The nitrogen content of recovered slops decreased as mycelial yield increased, indicating that the mold utilizes nitrogen for its growth. Increases in the pH of the slops were observed in all growth experiments conducted. Two mold strains compared favorably with the control mold strain in comparative mold screening tests among 12 strains investigated. Variations in protein content of mycelia were observed among the different strains studied. BOD reductions of slops were found proportional to mycelial yields, $30-53 \%$ after eight days' growth with the best strains tested.

\section{INTRODUCTION}

Consideration of the nutritional value of rum slops suggested its use as growth media for the production of fodder molds. These organisms are important sources of food because their cell matter is especially rich in most B-group vitamins and in protein that contain essential amino acids. Distillery slops proved to be a valuable medium for mold growth in a previous work at the Rum Pilot Plant ${ }^{3}$. Among 11 strains studied, best results were obtained with strain $\mathrm{H}-13$, Aspergillus phoenicis, isolated from contaminated slops in our laboratory and identified by Dr. Dorothy Fennell from the Northern Regional Research Laboratory, U.S. Department of Agriculture. A maximum yield of $17 \mathrm{~g} / 1$ was obtained after a four-day growth in laboratory scale experiments.

Mold mycelium obtained from slops could be used as animal feed supplement, and for this purpose interest in nitrogen content of mycelia deserved our attention in the present research.

\section{MATERIALS AND METHODS}

Molds used in this work (H-14 to $\mathrm{H}-24$ ) were obtained from the Northern Regional Research Laboratory, Illinois. They were previously

${ }^{1}$ Manuscript submitted to Editorial Board July 20, 1978.

${ }^{2}$ Associate Chemist and Bacteriologist, respectively, Agricultural Experiment Station, Mayagüez Campus, University of Puerto Rico, Rio Piedras, P.R.

${ }^{3}$ González, I. M. and Murphy, N. F., Potential use of rum distillery slops as animal feed supplement. I. Mold growth in rum distillery slops, submitted for publication, Rum Pilot Plant, Agricultural Experiment Station, University of Puerto Rico, Río Piedras, P.R. 
used by Chah et al. ${ }^{4}$ in the manufacture of edible protein. $\mathrm{H}-13$, a mold isolated at the RPP, was also included as control for its good growth in slops and high BOD reduction of the same.

\section{H-13: Aspergillus phoenicis \\ H-14: NRRL 5913-Aspergillus sydowi \\ H-15: NRRL 451-Aspergillus oryzae \\ H-16: NRRL 506-Aspergillus oryzae \\ H-17: NRRL 1720-Aspergillus candidus \\ H-18: NRRL 147-Aspergillus restrictus \\ H-19: NRRL 4-Aspergillus clavatus \\ H-20: NRRL 696-Aspergillus oryzae \\ $\mathrm{H}-21$ : NRRL 2220-Aspergillus oryzae \\ H-22: NRRL 450-Aspergillus flavus \\ H-23: NRRL 3518-Aspergillus flavus \\ H-24: NRRL 242-Aspergillus sydowi}

Laboratory scale experiments were performed with the purpose of studying protein nitrogen yield and protein nitrogen distribution during mold growth in the slopsmycelium combination. Mold strain H-13 was inoculated in Erlenmeyer flasks containing $250 \mathrm{ml}$ crude slops, shaken continuously in a mechanical shaker and harvested periodically. Nitrogen content was determined in both the mycelium and the supernatant and dry mycelial yield established. Total sugar ${ }^{5}, \mathrm{pH}$ and $\mathrm{BOD}^{6}$ analyses were performed in some experiments.

Comparative laboratory scale growth experiments were conducted for selection of best strains in terms of visual biomass production and BOD reduction. Separate portions of $250 \mathrm{ml}$ portions of sterile slops were placed in $500 \mathrm{ml}$ Erlenmeyer flasks and individually inoculated with each strain and constantly agitated mechanically for seven days. Mycelium was separated by filtration through Gooch filters and weighed. The supernatant was analyzed for BOD, and for $\mathrm{K}$ and Ca content by atomic absorption methods.

With the same procedure the best eight strains were then evaluated for mycelium yield, protein content and BOD slops reduction.

\section{RESULTS AND DISCUSSION}

Tables 1 and 2 and figure 1 present results on mold strain $\mathrm{H}-13$ growth in slops. Mycelial yield increased even after the final day growth period.

\footnotetext{
${ }^{4}$ Chah, C. C., Carlson, C. W., Seminiuk, G., Palmer, I. S., and Hesseltine, C. W., Growth promoting effects of fermented soybeans for broilers, Poultry Science 54, 600-9, 1975.

${ }^{5}$ Official analytical methods of the Rum Pilot Plant Agricultural Experiment Station, Mayagüez Campus, University of Puerto Rico, January 1969.

${ }^{6}$ Standard methods for the examination of water and wastewater, 14th ed., 1975.
} 
Nitrogen content in supernatant decreased as mycelial yield increased, indicating that the microorganism utilizes the nitrogen content of slops for its growth. Mycelium was richer in protein content at 24-48 hours growth attaining levels up to $32 \%$. After that time, the nitrogen content of the mycelium started to decrease. Reductions of $58 \%$ BOD and $59 \%$ total sugars reduced the polluting power of slops. Another improvement observed in slops, after mold growth, was the increase in $\mathrm{pH}$, from 4 to 5 to 5 to 7 .

Tables 3 and 4 present results of mold screening tests in slops. Strains

TABLE 1,-Mold growth in slops-Strain H-13

\begin{tabular}{ccccc}
\hline Harvest time & Total sugar $^{1}$ & BOD $^{2}$ & Mycelium & $\begin{array}{c}\text { Protein in } \\
\text { mycelium }\end{array}$ \\
\hline Days & $g / 100 m l$ & $p / m$ & $g / l$ & $\%$ \\
0 & 1.43 & 31,250 & - & - \\
1 & - & - & 3.1 & 27 \\
2 & - & - & 8.9 & 32 \\
3 & - & - & 14.2 & 25 \\
4 & - & - & 16.0 & 24 \\
5 & - & - & 18.0 & 22 \\
8 & 0.58 & 13,019 & 20.2 & 21 \\
\hline
\end{tabular}

${ }^{1}$ Total sugar reduction $=59 \%$.

${ }^{2}$ BOD reduction $=58 \%$.

TABLE 2.-Nitrogen distribution during mold growth in slops-Strain H-13

\begin{tabular}{cccccc}
\hline Harvest time & $\begin{array}{c}\text { Supernatant } \\
\text { pH }\end{array}$ & $\begin{array}{c}\text { Supernatant } \\
\text { total N }\end{array}$ & Mycelium & $\begin{array}{c}\text { Total N in } \\
\text { mycelium }\end{array}$ & $\begin{array}{c}\text { Protein in } \\
\text { mycelium }\end{array}$ \\
\hline Days & & $m g$ & $g / l$ & $m g$ & $\%$ \\
0 & 4.6 & 293 & - & - & - \\
1 & 4.8 & 257 & 2.4 & - & 26 \\
2 & 5.0 & 220 & 6.3 & 67.4 & 23 \\
3 & 5.0 & 218 & 7.0 & 70.6 & 22 \\
4 & 5.0 & 219 & 9.4 & 79.1 & 19 \\
5 & 5.3 & 226 & 10.0 & 80.8 & 17 \\
6 & 5.4 & 195 & 10.8 & 83.0 & 17 \\
7 & 5.4 & 185 & 11.6 & 88.8 & 17 \\
8 & 6.2 & 170 & 12.5 & 88.1 & 15 \\
\hline
\end{tabular}

H-14, 18 and 24 showed poor or no growth. Strains H-21 and 23 compared favorably with control strain $\mathrm{H}-13$ in both mycelial yield and BOD reduction. A relation was observed between mold growth and an increase in $\mathrm{pH}$ of the medium, the $\mathrm{pH}$ remained low when no growth was observed. Little variation was observed in $K$ and Ca content. Variation in protein content of mycelia was observed with the different strains studied. BOD reduction of slops was found to be proportional to mycelial yields, attaining $30-53 \%$ reductions after a 7-day growth with the strains which gave better results. 


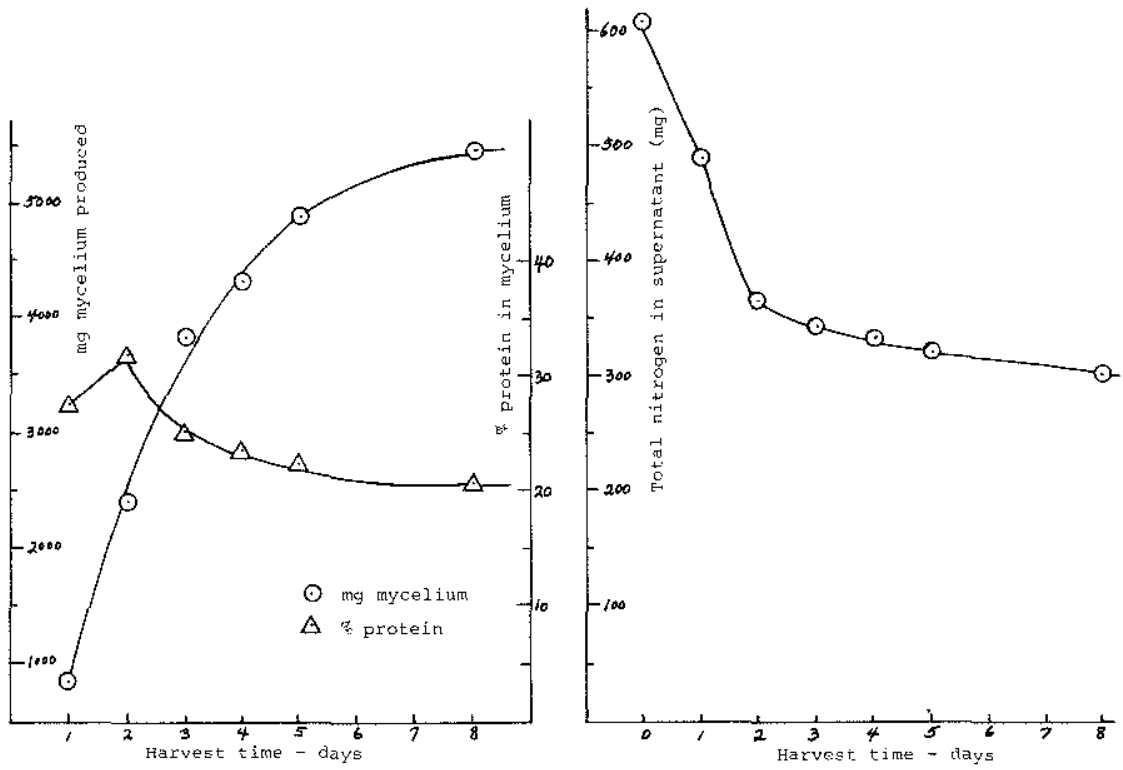

FIG. 1.-Mold growth in slops-strain H-13.

TABLE 3.-Comparative growth of mold strains in slops

\begin{tabular}{ccrcccc}
\hline $\begin{array}{c}\text { Mold } \\
\text { Strain }\end{array}$ & BOD & $\Delta$ BOD & $\begin{array}{c}\text { BOD } \\
\text { Reduction }\end{array}$ & K & Ca & pH \\
\hline & $p / m$ & & $\%$ & $\%$ & $\%$ & \\
H-13 & 33,000 & - & - & 1.53 & 0.23 & 4.6 \\
H-14 & 20,000 & 13,000 & 39 & 1.18 & 0.19 & 5.3 \\
H-15 & 32,500 & 500 & 1 & 1.07 & 0.22 & 4.6 \\
H-16 & 22,500 & 10,500 & 32.5 & 1.01 & 0.21 & 5.4 \\
H-17 & 27,500 & 5,500 & 17 & 0.96 & 0.22 & 5.3 \\
H-18 & 32,000 & 10,000 & 30 & 1.11 & 0.24 & 5.6 \\
H-19 & 23,000 & 1,000 & 3 & 1.07 & 0.24 & 4.6 \\
H-20 & 26,000 & 10,000 & 30 & 0.96 & 0.21 & 5.5 \\
H-21 & 19,000 & 1,000 & 21 & 0.96 & 0.22 & 5.5 \\
H-22 & 24,000 & 9,000 & 42 & 1.01 & 0.20 & 5.9 \\
H-23 & 20,500 & 12,500 & 27 & 1.01 & 0.22 & 5.7 \\
H-24 & 30,500 & 2,500 & 83 & 1.07 & 0.23 & 5.8 \\
\hline
\end{tabular}

\section{RESUMEN}

El mosto de destilerías de ron resultó útil para el cultivo de hongos cuyo micelio puede utilizarse como alimento suplementario para animales. Se obtuvieron reducciones altas en el BOD y azúcares totales del mosto. El contenido en nitrógeno bajó a medida que aumentó el rendimiento de micelio, indicando que el hongo lo utiliza para su crecimiento. 
TABLE 4.-Comparative growth of mold strains in slops

\begin{tabular}{|c|c|c|c|c|c|c|c|c|c|}
\hline $\begin{array}{l}\text { Mold } \\
\text { Strain }\end{array}$ & BOD & $\triangle \mathrm{BOD}$ & $\begin{array}{c}\mathrm{BOD} \\
\text { Reduction }\end{array}$ & $\mathrm{Ca}$ & $\mathrm{K}$ & $\mathrm{pH}$ & $\begin{array}{l}\text { Mycelium } \\
\text { yield }\end{array}$ & $\begin{array}{c}\text { Protein } \\
\text { in mycelium }\end{array}$ & $\begin{array}{c}\text { Supernatant } \\
\text { protein }\end{array}$ \\
\hline & $p / m$ & & $\%$ & $\%$ & $\%$ & & $g / l$ & $\%$ & $m g / 100 \mathrm{ml}$ \\
\hline- & 32,100 & - & - & 0.29 & 1.31 & 4.8 & - & - & 1107 \\
\hline H-13 & 21,000 & 11,100 & 35 & 0.22 & 1.27 & 5.5 & 16.8 & 19.4 & 773 \\
\hline H-15 & 20,800 & 11,300 & 35 & 0.25 & 1.18 & 5.5 & 14.7 & 25.4 & 629 \\
\hline H-16 & 18,500 & 13,600 & 42 & 0.25 & 1.31 & 6.5 & 18.0 & 23.9 & 564 \\
\hline H-17 & 22,400 & 9,700 & 30 & 0.25 & 1.31 & 5.8 & 13.9 & 24.3 & 794 \\
\hline H-19 & 22,100 & 10,000 & 31 & 0.25 & 1.22 & 6.0 & 10.5 & 25.8 & 909 \\
\hline $\mathrm{H}-20$ & 18,100 & 14,000 & 44 & 0.25 & 1.18 & 5.9 & 17.9 & 23.3 & 710 \\
\hline $\mathrm{H}-2 \mathrm{I}$ & 16,700 & 15,400 & 48 & 0.25 & 1.20 & 6.1 & 17.8 & 21.5 & 654 \\
\hline $\mathrm{H}-22$ & 18,400 & 13,700 & 43 & 0.24 & 1.18 & 6.6 & 17.3 & 22.9 & 704 \\
\hline H-23 & 15,100 & 17,000 & 53 & 0.25 & 1.18 & 6.9 & 20.8 & 20.6 & 690 \\
\hline
\end{tabular}


Se observó un aumento en el pH del mosto cuando los hongos crecieron. De 12 cepas de hongos dos compararon favorablemente con la cepa control. Se observaron variaciones en el contenido proteico del micelio entre las cepas investigadas. Las reducciones en el BOD del mosto fueron proporcionales al rendimiento de micelio. Con las cepas que dieron mejores resultados se obtuvieron reducciones de $30-53 \%$ BOD al cabo de 7 días de crecimiento. 